\title{
The Application of Children's Learning in Science (CLIS) Model With Flip Chart Media in Increasing Science Learning about Force in Grade V Students of SD Negeri Wiromartan in Academic Year 2018/2019
}

\author{
Lhinatul Arivvia Rachma' ${ }^{1}$, Tri Saptuti Susiani ${ }^{2}$, Ngatman $^{3}$ \\ 1,2,3 Universitas Sebelas Maret \\ Ihinatul03@gmail.com
}

\section{Article History \\ accepted 01/06/2019}

approved 01/07/2019 published 01/08/2019

\begin{abstract}
This study aimed to describe the steps to implement the CLIS model with flip chart media and improve science learning through the application of the CLIS model with flip chart media. This research is a collaborative classroom action research (PTK) with teachers conducted in three cycles. The data used were quantitative and qualitative data. Data collection techniques used observation, interviews, and tests. Data validity used technique triangulation and sources. Data analysis was carried out through data reduction, data presentation, and conclusion. The results showed that the application of the CLIS model with flip chart media was carried out with five steps, namely: (a) orientation to use flip chart media, (b) idea generation, (c) idea rearrangement, (d) application of ideas, (e) consolidation of ideas by using flip chart media. The application of the CLIS model with flip chart media could improve science learning which is known through increasing the percentage of the results of the assessment of process skills in the first cycle of $71.67 \%$, cycle II was $83.33 \%$, and cycle III was $88.35 \%$. The result of attitude assessment in the first cycle was $66.68 \%$, second cycle was $79.19 \%$, and cycle III was $87.75 \%$. The completeness percentage of students in cycle I was $82.26 \%$, in cycle II was $93.54 \%$, and in cycle III was $96.77 \%$.
\end{abstract}

Keywords: Learning In Science Children (CLIS), flip charts, science, force

\section{Abstrak}

Penelitian ini bertujuan untuk menggambarkan langkah-langkah untuk mengimplementasikan model CLIS dengan media flip chart dan meningkatkan pembelajaran sains melalui penerapan model CLIS dengan media flip chart. Penelitian ini adalah penelitian tindakan kelas kolaboratif (PTK) dengan guru dilakukan dalam tiga siklus. Data yang digunakan adalah data kuantitatif dan kualitatif. Teknik pengumpulan data menggunakan observasi, wawancara, dan tes. Validitas data menggunakan teknik triangulasi dan sumber. Analisis data dilakukan melalui reduksi data, penyajian data, dan penarikan kesimpulan. Hasil penelitian menunjukkan bahwa penerapan model CLIS dengan media flip chart dilakukan dengan lima langkah, yaitu: (a) orientasi untuk menggunakan media flip chart, (b) generasi ide, (c) penyusunan kembali ide, (d) penerapan ide, (e) konsolidasi ide dengan menggunakan media flip chart. Penerapan model CLIS dengan media flip chart dapat meningkatkan pembelajaran sains yang diketahui melalui peningkatan persentase hasil penilaian keterampilan proses pada siklus pertama $71,67 \%$, siklus II 83,33\%, dan siklus III 88,35\%. . Hasil penilaian sikap pada siklus I adalah $66,68 \%$, siklus II 79,19\%, dan siklus III $87,75 \%$. Persentase ketuntasan siswa pada siklus I adalah $82,26 \%$, pada siklus II adalah $93,54 \%$, dan pada siklus III adalah $96,77 \%$.

Kata kunci: Learning In Science Children (CLIS), flip chart, sains, kekuatan 


\section{PENDAHULUAN}

IPA merupakan suatu ilmu yang sistematis tentang gejala-gejala alam. Badan Standar Nasional Pendidikan (2006:162) mengemukakan bahwa tujuan pembelajaran IPA di sekolah dasar adalah agar siswa dapat mengembangkan pemahaman mengenai konsep-konsep IPA dan meningkatkan keterampilan proses menggunakan metode ilimiah dan sikap ilmiah guna memecahkan masalah-masalah yang dihadapi dengan lebih menyadari akan keindahan, keberadaan, dan keteraturan alam ciptaan Tuhan.

Berdasarkan hasil observasi dan wawancara dengan guru kelas V SD Negeri Wiromartan ditemukan 3 fakta yang menunjukkan bahwa pembelajaran IPA di kelas tersebut belum sesuai dengan yang diharapkan. Pertama, model dan media pembelajaran yang digunakan guru sudah bervariasi. Hanya saja dalam pelaksanaannya, pembelajaran masih cenderung menggunakan model pembelajaran yang bersifat konvensional sehingga siswa kurang terlibat secara aktif. Kedua, kebermaknaan pembelajaran bagi siswa masih kurang. Hal ini terlihat dari kurangnya perhatian siswa pada saat pembelajaran berlangsung. Ketiga, hasil belajar IPA masih tergolong rendah.

Berdasarkan permasalahan yang dipaparkan, maka perlu adanya perbaikan pada pembelajaran IPA. Salah satu solusinya yaitu dengan menerapkan model CLIS. Hidayat, dkk. (2018: 17) mengemukakan bahwa, "CLIS model is a model of learning that seeks to develop the ideas or ideas of learners about a particular problem in learning and reconstruct ideas or ideas based on observations or experiments. Learners are trained to argue after making observations or experiments. In addition CLIS model is a learning model that is in accordance with the nature of science". Wiyase (2015: 2) juga berpendapat bahwa model pembelajaran CLIS merupakan model pembelajaran yang memiliki karakteristik berdasarkan paradigma konstruktivisme dengan memperhatikan pengetahuan awal siswa yang kemudian dikembangkan melalui kegiatan ilmiah. Melalui model pembelajaran ini, siswa diberi kesempatan untuk mengungkapkan, membandingkan, mendiskusikan, merekontruksi dan mengaplikasikan ide atau gagasan tentang topik permasalahan yang dibahas dalam pembelajaran.

Selain model pembelajaran, penggunaan media yang inovatif juga dibutuhkan dalam proses pembelajaran. Adapun media yang digunakan dalam penelitian ini adalah media flip chart. Menurut Indriana (2011:66) media flip chart adalah lembaran dengan bentuk album atau kalender dan berukuran sedikit besar sebagai flipbook, disusun sesuai urutan yang bagian atasnya diikat. Media ini bisa diisi gambar, huruf, angka, dan diagram. Selanjutnya, Anitah (2009: 20) menjelaskan bahwa, flip chart merupakan susunan dari berbagai gambar dan digantung pada tiang gantungan kecil. Penggunaan media ini dengan menunjukkan gambar tersebut dengan dibalik satu per satu.

Berdasarkan uraian di atas, peneliti tertarik untuk melaksanakan penelitian tindakan kelas secara kolaboratif bersama guru kelas $\mathrm{V}$ dengan judul "Penerapan Model Children's Learning In Science (CLIS) dengan Media Flip chart dalam Peningkatan Pembelajaran IPA tentang Gaya pada Siswa Kelas V SD Negeri Wiromartan Tahun Ajaran 2018/2019". Diharapkan dengan penelitian ini dapat meningkatkan pembelajaran IPA.

Berdasarkan uraian di atas, maka dapat dirumuskan masalah yaitu: (1) bagaimanakah langkah-langkah penerapan model CLIS dengan media flip chart? dan (2) apakah penerapan model CLIS dengan media flip chart dapat meningkatkan pembelajaran IPA tentang gaya pada siswa kelas V SD Negeri Wiromartan tahun ajaran 2018/2019?

Penelitian ini bertujuan untuk: (1) mendeskripsikan langkah-langkah penerapan model CLIS dengan media flip chart dan (2) meningkatkan pembelajaran IPA tentang 
gaya melalui penerapan model CLIS dengan media flip chart pada siswa kelas V SD Negeri Wiromartan tahun ajaran 2018/2019.

\section{METODE}

Penelitian ini merupakan penelitian tindakan kelas (PTK) kolaboratif dengan guru yang dilaksanakan dalam tiga siklus. Subjek penelitian ini adalah guru dan siswa kelas $\mathrm{V}$ yang berjumlah 31 siswa. Jenis data dalam penelitian ini adalah data kuantitatif dan data kualitatif. Data kuantitatif berupa hasil penilaian keterampilan proses, sikap, dan hasil belajar pada mata pelajaran IPA. Data kualitatif berupa hasil observasi dan wawancara. Sumber data dalam penelitian ini yaitu guru dan siswa kelas V. Teknik pengumpulan data menggunakan observasi, wawancara, dan tes. Uji validitas data menggunakan triangulasi teknik dan sumber. Analisis data meliputi reduksi data, penyajian data, dan kesimpulan sesuai model analisis data menurut Miles dan Huberman (Sugiyono, 2012: 246-253).

Indikator kinerja penelitian ini adalah peningkatan pembelajaran siswa dalam mata pelajaran IPA dengan ketercapaian target 85\%. Penelitian ini menggunakan prosedur penelitian Kemmis dan Taggart (Arikunto, 2013: 137), yaitu terdiri dari tahap perencanaan, pelaksanaan, pengamatan, dan refleksi.

\section{HASIL DAN PEMBAHASAN}

Penelitian ini dilaksanakan tiga siklus dengan menerapkan lima langkah model CLIS dengan media flip chart yaitu: (1) orientasi menggunakan media flip chart, (2) pemunculan gagasan, (3) penyusunan ulang gagasan, (4) penerapan gagasan, (5) pemantapan gagasan menggunakan media flip chart.

Hasil observasi penerapan model CLIS dengan media flip chart terhadap guru dan siswa mengalami peningkatan pada setiap siklusnya yaitu:

Tabel 1. Persentase Hasil Observasi Guru dan Siswa

\begin{tabular}{|c|c|c|c|}
\hline \multirow{2}{*}{$\begin{array}{l}\text { Sumber } \\
\text { Data }\end{array}$} & \multicolumn{3}{|l|}{ Siklus } \\
\hline & I & || & III \\
\hline & 70,32 & 85,17 & 94,75 \\
\hline & 69,08 & 83,72 & 89,45 \\
\hline
\end{tabular}

Hasil observasi terhadap guru dari siklus I ke siklus II mengalami peningkatan sebesar $14,85 \%$ dan dari siklus II ke siklus III mengalami peningkatan sebesar 9,58\%. Hasil observasi terhadap siswa dari siklus I ke siklus II mengalami peningkatan sebesar $14,64 \%$ dan dari siklus II ke siklus III mengalami peningkatan sebesar 5,73\%.

Tabel 2. Hasil Penilaian Pembelajaran IPA

\begin{tabular}{llll}
\hline Sumber Data & \multicolumn{2}{l}{ Siklus } & \\
\cline { 2 - 4 } & I & II & III \\
\hline $\begin{array}{l}\text { Keterampilan } \\
\text { Proses (\%) }\end{array}$ & 71,67 & 84,15 & 91,65 \\
$\begin{array}{l}\text { Sikap (\%) } \\
\text { Ketuntasan } \\
\text { (\%) }\end{array}$ & 86,69 & 83,31 & 91,26 \\
\hline
\end{tabular}

Hasil penilaian pembelajaran IPA pada siklus I, siklus II, dan siklus III selalu mengalami peningkatan. Hasil keterampilan proses IPA dari siklus I ke siklus II mengalami peningkatan sebesar $12,51 \%$ dan dari siklus II ke siklus III meningkat sebesar $8,56 \%$. Hasil penilaian sikap IPA siklus I ke siklus II mngalami peningkatan 
sebesar $16,62 \%$ dan dari siklus II ke siklus III mengalami peningkatan sebesar 7,94\%. Persentase ketuntasan siswa dari siklus I ke siklus II mengalami peningkatan sebesar $11,28 \%$ dan dari siklus II ke siklus III sebesar 3,23\%.

Berdasarkan tabel 1 dapat disimpulkan bahwa penerapan model pembelajaran CLIS dengan media flip chart sudah dilaksanakan dengan baik dan sudah mencapai target indikator kinerja penelitian sebesar $85 \%$. Selanjutnya, berdasarkan tabel 2 dapat disimpulkan bahwa hasil pembelajaran IPA sudah mencapai target indikator kinerja penelitian sebesar $85 \%$ dan meningkat di setiap siklusnya.

Hal tersebut sesuai dengan penelitian yang dialkuakan oleh Kurniasih, Jampel, dan Riastini (2016: 1-9) yang telah membuktikan bahwa penerapan model CLIS dapat meningkatkan hasil belajar IPA. Penelitian Eka (2013: 10) membuktikan bahwa penggunaan media flip chart dapat meningkatkan hasil belajar siswa sekolah dasar.

\section{SIMPULAN}

Berdasarkan uraian hasil penelitian dan pembahasan, maka dapat disimpulkan bahwa: (1) penerapan model CLIS dengan media flip chart dilakukan dengan lima langkah yaitu: (a) orientasi menggunakan media flip chart, (b) pemunculan gagasan, (c) penyusunan ulang gagasan, (d) penerapan gagasan, (e) pemantapan gagasan menggunakan media flip chart; dan (2) penerapan model CLIS dengan media flip chart dapat meningkatkan pembelajaran siswa IPA pada siswa Kelas V SD Negeri Wiromartan tahun ajaran 2018/2019 yang dibuktikan dengan peningkatan persentase hasil penilaian pembelajaran IPA.

\section{DAFTAR PUSTAKA}

Anitah, S. (2009). Media Pembelajaran. Surakarta: Panitia Sertifikasi Guru Rayon 13 FKIP UNS Surakarta.

Arikunto, S. (2013). Prosedur Penelitian: Praktik. Jakarta: Rineka Cipta.

Badan Standar Nasional Pendidikan. (2006). Standar Isi untuk Satuan Pendidikan Dasar, Menengah Standar Kompetensi, dan Kompetendi Dasar SD/MI. Jakarta: Kementrian Pendidikan Nasional.

Eka. (2013). Penerapan Media Papan Balik (Flipchart) pada Pembelajaran Tematik untuk Meningkatkan Hasil Belajar Siswa Sekolah Dasar. JPGSD, 01 (02), 1-10.

Hidayat, A., dkk. (2018). Children Learning In Science On Improvement Of Learning Results In SDN 1 Sudimampir. Journal of Elementary Education, 1 (1), 16-25. Diperoleh pada 6 September 2018, dari http://journal. Ikipsiliwangi.ac.id/index.php/collase/article/view/50/24.

Indriana, D. (2011). Ragam Alat Bantu Media Pengajaran. Wonosari: Diva Press.

Kurniasih, T., Jampel, I.N., \& Riastini, N.P. (2016). Penerapan Model Clis untuk Meningkatkan Hasil Belajar IPA Siswa Kelas V SD. e-Jurnal PGSD Universitas Pendidikan Ganesha, 4 (1), 1-10. Diperoleh pada 6 November 2018 dari https://journal.univganesha.ac.id/sju/index.php/jee/article/download/7537/5327.

Sugiyono. (2012). Metode Penelitian Pendidikan (Pendekatan Kuantitatif, Kualitatif, dan $R \& D)$. Bandung: Penerbit Alfabeta.

Wiyase. (2015). Pengaruh Penerapan Model Pembelajaran Children Learning In Scienceterhadaphasil Belajar Pendidikan Jasmani. Jurnal Sport Pedagogy, 5 (1), 28-31. Diperoleh pada 6 November 2018 dari www.jurnal.unsyia h.ac.id/JSP/article/download/7316/6016. 